\section{Derek Peter Merfield}

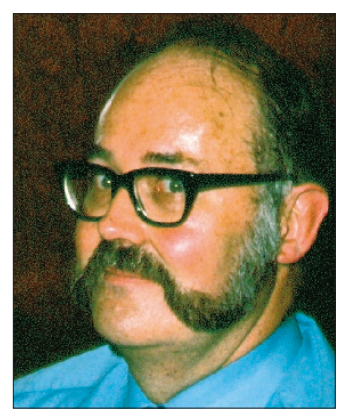

Derek died on the 13 April 2003 from a cerebral haemorrhage, following a series of strokes over the last 18 months. He qualified in Melbourne Australia in 1955, and came to the UK and entered general practice in 1957.

Derek had a number of interests outside dentistry. He was a wellknown saloon car racing driver in the 1960 s with many wins to his credit. Gliding was another of his hobbies and he was an accomplished photographer, becoming an associate of the Royal Photographic Society and president of the Camera Club. He was also very interested in stereoscopic photography and he was also an active member of that society and was editor and printer of the society magazine.

Derek survived severe mercury poisoning following a spillage of mercury under the sterilizer in 1974, which contaminated the practice premises. He was, soon after, to lose a finger due to a sarcoma, which terminated his career in dental practice, but not his interest in dentistry.

Derek was elected to the Merton, Sutton and Wandsworth local dental committee when it was set up in 1974 and was an active member, taking over the production of the LDC newsletter in 1978. Often controversial, it kept the local dentists up to date on NHS dental policy and politics. He also lectured at post graduate level to vocational trainees.

\section{In his retirement he took up offset} printing and edited and printed a number of club and society magazines. He undertook a certificate of higher education in industrial architecture and a degree in philosophy.

In his retirement he took up offset printing and edited and printed a number of club and society magazines. He undertook a certificate of higher education in industrial architecture, and a degree in philosophy. He travelled extensively, in Europe, the USA, Australia and New Zealand, covering many thousands of miles in his campervans.

He was always a keen skier and in spite of having a coronary bypass, following a coronary while skiing, he continued to enjoy skiing holidays, both in Europe and the USA until four years ago.

Derek was a Humanist and as a member of the Sutton Humanist Society, a fellow Humanist conducted his cremation ceremony, which was well attended by many of his old friends.

His daughter Helen and son Charles survive him

Charles Merfield

\title{
Henry Randell Carter
}

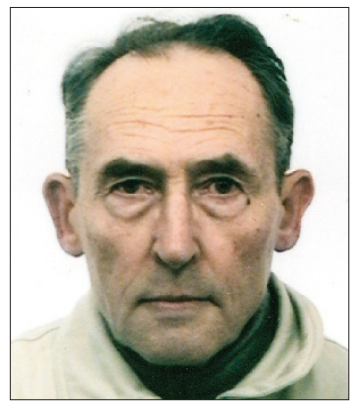

Henry Randell Carter BDS was born on 19th March 1932, graduated 3rd July 1956 from the University of Durham and died 9th May 2003

Henry Randell Carter, known always as "Harry", originally left school at 16 years of age to join the Merchant Navy. After two years of Atlantic crossings to and from the St. Lawrence Seaway, he settled

As a dental surgeon he was always meticulous and methodical in his work. He was an accomplished, self-taught flautist and an excellent baker and home brewer. down as a student of Durham University at the Dental School, Newcastle upon Tyne. He qualified in 1956, winning the prize in his year for practical work.

After completing National Service in Malaysia, he worked in practice in London, Isle of Sheppey and finally in Cleveland for the Community Dental Service until his retirement in 1992.

As a dental surgeon he was always meticulous and methodical in his work. These qualities were carried over into his home life, where he was skilled at making and repairing things around the home. He was an accomplished, self-taught flautist and an excellent baker and home brewer.

His wife Dolly, also a dental surgeon, his daughter Avis, a law lecturer and son Jim, a doctor will sadly miss him.

Jim Carter

David Poswillo CBE.

There will be a memorial service for Professor David Poswillo at GKT Dental Institute, Guy's Hospital Chapel, London, on Thursday 16th October 2003 at 11.00 am followed by a reception in Atrium 1 at 12.00 noon. RSVP Mrs Sandi 02079554342. 